\title{
Distribution pattern of larval fish populations in the Northwestern Mediterranean
}

\author{
Ana Sabatés \\ Institut de Ciències del Mar, Passeig Nacional s/n, E-08003 Barcelona, Spain
}

\begin{abstract}
Spatiotemporal distribution patterns in the larval fish community were studied off the Catalan coast (NW Mediterranean) between April and October 1983. Important seasonal variations in species composition were detected. The causes of this temporal heterogeneity lay in the species richness of the area and the spawning periods of adults. Spatial heterogeneity depended on the combined effects of topography and hydrographic features of the region. The existence of a shelf-slope front along the shelf break was one of the most important factors and was associated with maximum larval abundance. The current running along the coast from north to south together with the diversity of bottom structure and type also made major contributions to spatial heterogeneity. Four distinct geographical zones coinciding with bottom features were differentiated by statistical analysis. The species groups defining these 4 zones largely coincided with habitat and behaviour of the adults. However, with the diversity of features of the region, the species were not limited solely to a single assemblage, giving rise to a gradation rather than to well-defined associations.
\end{abstract}

\section{INTRODUCTION}

In recent decades the study of fish larvae, like that of other zooplankton groups, has mainly concentrated on community structure and dynamics in relation to the hydrodynamics of the medium in which they live. Investigations aimed at defining the mechanisms by which environmental features and events regulate the distribution and abundance of larval fish populations and other zooplankton groups have recently been reviewed (e.g. Denman \& Powell 1984, Haury \& Pieper 1988). Many observations indicate that a heterogeneous distribution of fish larvae, and other zooplankton groups, is brought about by the differential response of organisms to hydrodynamic and biological processes as a function of the spatial or temporal scale of these processes (Mackas et al. 1985).

Like other zooplankton, fish larvae exhibit community distribution patterns related to mesoscale hydrographic variability (Legendre \& Demers 1984). In this regard, advection processes such as currents (e.g. Richardson \& Pearcy 1977, Richardson et al. 1980) or eddies (Lobal \& Robinson 1986) have been considered causes of horizontal larval distribution patterns. Moreover, in coastal regions the structure of the continental shelf plays a very important role in determining the spatial distribution of fish larvae (Leis \& Miller 1976. Young et al. 1986). Hydrographic processes are to some extent responsible for seasonal variations, although biological processes may provide better explanations of seasonal distribution patterns of fish larvae. Such biological processes include adult distribution, spawning area and season, and the survival rate of larvae in the plankton (Walker et al. 1987, Shapiro et al. 1988).

The purpose of the present paper is to ascertain the processes and factors affecting the spatiotemporal distribution of fish larvae off the Catalan coast, in the Northwestern Mediterranean. Knowledge of the distribution pattern of the larval fish community will, in turn, assist in determining to what extent community structure is related to local hydrodynamics, continental shelf topography and species biology.

\section{STUDY AREA}

The width of the Catalan continental shelf is extremely variable. Shelf topography in the northern part of the area is characterized by the presence of 2 submarine canyons approaching to within a few miles of the coast; between the canyons, the shelf is $40 \mathrm{~km}$ broad. In the central part of the area, the shelf is narrow and rather regular, while in the southern portion it broadens abruptly again to $50 \mathrm{~km}$ opposite the Ebro River delta (Fig. 1).

The distribution of substrate types on the shelf is 


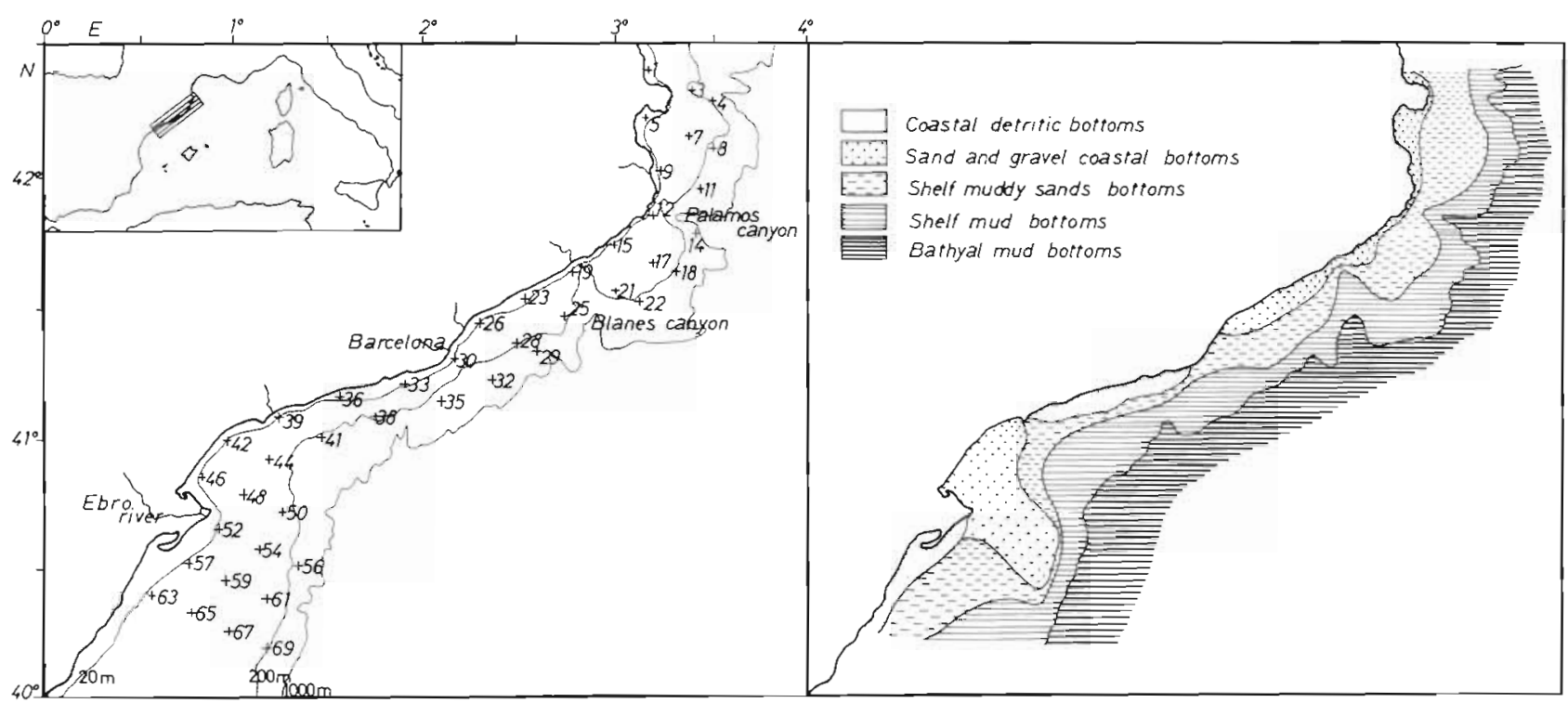

Fig. 1 Left: The study area showing the 44 monthly sampling stations. Right: Schematic representation of the main bottom types off Catalan coast, after Gili et al. (1987)

highly diverse. Bottoms of sand and sea grasses are located inshore close to the coast within the $60 \mathrm{~m}$ isobath. They attain their maximum extent in the northern and southern parts of the study area. Combined sandy and muddy substrates extend through the area at greater depths. Muddy bottoms are located along the edge of the shelf (Gili et al. 1987) (Fig. 1).

The hydrodynamics of the shelf waters are also quite variable. The current in the region, a continuation of the Liguro-Provençal current, flows towards the southwest along the coast some $55 \mathrm{~km}$ offshore, approximately along the edge of the continental shelf (Font 1986). Associated with this current is a front separating less saline inshore waters from open sea waters (Salat \& Font 1987. Font et al. 1988). It is a typical permanent shelf-slope front, although it may display great spatiotemporal instability (Wang et al. 1988).

\section{MATERIALS AND METHODS}

Samples were taken during 6 monthly surveys between April and October (excluding August) 1983. This is the spawning season for most Mediterranean fish species (Aboussouan 1964, Marinaro 1971). A grid consisting of 44 stations on 17 transects perpendicular to the coast covering the entire continental shelf was sampled on each cruise (Fig. 1). The number of stations on each transect depended on shelf width. The distance between stations, and between transects, was ca $18 \mathrm{~km}$.

Plankton hauls were made using a Bongo net with a mouth diameter of $40 \mathrm{~cm}$ and a mesh size of $300 \mu \mathrm{m}$. The volume of water passing through the net during each haul was measured by a flowmeter attached to the mouth of the net. Hauls were oblique, from just above the bottom to the surface, or from $200 \mathrm{~m}$ to the surface where bottom depth was greater. Samples were fixed in $5 \%$ borax-buffered formalin immediately after capture. Data were standardized to number of larvae $10 \mathrm{~m}^{-2}$.

Principal component analyses (PCA) were applied in order to obtain an objective description of the distribution patterm for the multispecies population sampled. This methodology has been widely employed in the study of zooplankton communities (e.g. Colebrook 1964, Ibanez \& Seguin 1972). Only species present in at least $10 \%$ of the samples were included. A correlation matrix was used and data were first smoothed by a logarithmic transformation (Ibanez 1976). One overall PCA was performed on the entire data set for all 6 mo studied, using a total of 264 samples (stations) and 46 species as descriptors. Seasonality was a major factor in the overall analysis and may have masked any other patterns contributing to the species distribution. Since the sampling points were the same for each month studied and in order to offset the effect of seasonality a second principal component analysis was performed with the average values (of the 6 mo studied) per station, with a total of 44 stations and 46 species. For convenience in interpreting the first 2 factors obtained in the second PCA, the values of the coordinates of the samples were plotted on the station map.

\section{RESULTS}

A total of 45 species, present in more than $10 \%$ of the samples, were considered in the present study (Table 1.). Species abundance and diversity varied 
Table 1. Monthly abundance estimates (N) expressed as mean of numbers per $10 \mathrm{~m}^{2}$; percentage of samples in which species occur

\begin{tabular}{|c|c|c|c|c|c|c|c|c|c|c|c|c|}
\hline \multirow[t]{2}{*}{ Species } & \multicolumn{2}{|c|}{ Apr } & \multicolumn{2}{|c|}{ May } & \multicolumn{2}{|c|}{ Jun } & \multicolumn{2}{|c|}{ Jul } & \multicolumn{2}{|c|}{ Sep } & \multicolumn{2}{|c|}{ Oct } \\
\hline & $N$ & $\%$ & $N$ & $\%$ & $N$ & $\%$ & $N$ & $\%$ & $N$ & $\%$ & N & $\%$ \\
\hline Sardina pilchardus & 81 & 75 & 33 & 29 & - & - & - & - & - & - & - & - \\
\hline Sardinella aurita & - & - & - & - & - & - & 601 & 11 & 374 & 68 & 25 & 12 \\
\hline Engraulis encrasicholus & - & - & 856 & 54 & 1677 & 95 & 2360 & 98 & 140 & 95 & 30 & 34 \\
\hline Cyclothone braueri & - & - & 10 & 7 & 41 & 16 & 41 & 43 & 80 & 68 & 23 & 82 \\
\hline Maurolicus muelleri & 69 & 29 & 28 & 16 & 11 & 16 & 30 & 25 & 24 & 4 & 51 & 2 \\
\hline Agryropelecus hemigymnus & 16 & 2 & 36 & 4 & 30 & 7 & 18 & 18 & 20 & 14 & 30 & 14 \\
\hline Stomias b boa & 17 & 20 & 13 & 2 & 8 & 2 & 23 & 4 & 13 & 4 & - & - \\
\hline Benthosema glaciale & 34 & 36 & 14 & 11 & 17 & 16 & 31 & 29 & 11 & 23 & 26 & 41 \\
\hline Hygophum hygomii & - & - & 10 & 7 & 27 & 16 & 17 & 25 & - & - & 20 & 18 \\
\hline Myctophum punctatum & 24 & 23 & 23 & 25 & 14 & 32 & 23 & 27 & 12 & 16 & 17 & 50 \\
\hline Lobianchia dofleini & - & - & - & - & 8 & 2 & 8 & 4 & - & - & 27 & 16 \\
\hline Lampanyctus crocodilus & 18 & 41 & 15 & 14 & 18 & 39 & 20 & 12 & 19 & 16 & 24 & 27 \\
\hline Lampanyctus pusillus & - & - & - & - & - & - & 10 & 9 & 8 & 2 & 19 & 20 \\
\hline Ceratoscopelus maderensis & - & - & 16 & 9 & 20 & 41 & 21 & 43 & 15 & 39 & 14 & 48 \\
\hline Notoscopelus elongatus & 33 & 43 & 9 & 9 & 16 & 36 & 12 & 2 & - & - & - & - \\
\hline Micromesistius poutassou & 14 & 16 & 19 & 14 & 17 & 2 & - & - & - & - & - & - \\
\hline Merluccius merluccius & 13 & 4 & 10 & 7 & 8 & 4 & 12 & 20 & 16 & 14 & 27 & 16 \\
\hline Ophidion barbatum & - & - & - & - & - & - & 32 & 45 & 32 & 64 & 44 & 61 \\
\hline Serranus cabrilla & - & - & - & - & 20 & 20 & 11 & 23 & - & - & - & - \\
\hline Serranus hepatus & - & - & 27 & 11 & 25 & 43 & 35 & 54 & 14 & 29 & - & - \\
\hline Pomatomus saltator & - & - & - & - & - & - & 35 & 25 & 22 & 34 & - & - \\
\hline Trachurus m. mediterraneus & - & - & - & - & - & - & 22 & 23 & 16 & 25 & - & - \\
\hline Trachurus trachurus & 15 & 29 & 26 & 50 & 32 & 43 & 13 & 25 & 10 & 9 & 7 & 9 \\
\hline Boops boops & 66 & 73 & 167 & 82 & - & - & - & - & - & - & - & - \\
\hline Diplodus s, sargus & 34 & 11 & 108 & 54 & - & - & - & - & - & - & - & - \\
\hline Oblada melanura & - & - & - & - & 101 & 68 & - & - & - & - & & - \\
\hline Pagellus acarne & - & - & - & - & - & - & 10 & 7 & 26 & 43 & 21 & 43 \\
\hline Sparus pagrus & - & - & 14 & 14 & 12 & 25 & 11 & 36 & 155 & 27 & - & - \\
\hline Sparidae Type 1 & - & - & 152 & 7 & 204 & 50 & 55 & 23 & - & - & - & - \\
\hline Cepola macrophtalma & - & - & 38 & 27 & 65 & 59 & 83 & 66 & 90 & 59 & 85 & 73 \\
\hline Liza saliens & - & - & - & - & - & - & - & - & 37 & 29 & 26 & 39 \\
\hline Mugil c cephalus & - & - & - & - & - & - & - & - & 22 & 9 & 40 & 57 \\
\hline Trachinus draco & - & - & - & - & - & - & 33 & 18 & 23 & 50 & 16 & 39 \\
\hline Callionymus maculatus & 30 & 43 & 43 & 41 & 28 & 41 & 12 & 16 & - & - & - & - \\
\hline Callionymus risso & 11 & 9 & 29 & 45 & 26 & 36 & 12 & 29 & - & - & 8 & 2 \\
\hline Gobius paganellus & - & - & -- & - & - & - & 10 & 20 & - & - & - & - \\
\hline Auxis rochei & - & - & - & - & - & - & 53 & 50 & 13 & 2 & - & - \\
\hline Sarda sarda & - & - & - & - & - & - & 11 & 25 & - & - & - & - \\
\hline Scomber japonicus & - & - & - & - & 28 & 9 & 41 & 39 & 46 & 23 & - & - \\
\hline Citharus macrolepidotus & - & - & - & - & - & - & - & - & 34 & 20 & 27 & 34 \\
\hline Arnoglossus laterna & 46 & 39 & 79 & 59 & 48 & 36 & 10 & 11 & - & - & - & - \\
\hline Arnoglossus thori & - & - & - & - & 103 & 23 & 37 & 43 & 18 & 34 & 17 & 25 \\
\hline Symphurus nigrescens & - & - & - & - & - & - & 22 & 20 & 20 & 27 & 23 & 25 \\
\hline Buglossidium luteun & 14 & 16 & 73 & 36 & 38 & 18 & 16 & 11 & - & - & - & - \\
\hline Solea lascaris & - & - & 11 & 11 & 9 & 7 & - & - & 26 & 7 & - & - \\
\hline
\end{tabular}

among the different months. The number of individuals was highest between May and June; in the remaining months larval abundance was lower by a factor of about 10. The number of species, on the other hand, showed less seasonal fluctuation. The variability in the number of individuals, in contrast to the constancy in species diversity, was due primarily to Engraulis encrasicholus, which accounted for a high proportion of the total number of individuals in June and July.

Spatially, larval concentrations tended to be greater at the stations furthest from the coast, although they were somewhat higher in the northern half of the area and at certain stations over the Blanes canyon. The maximum number of species per station coincided with the localities with highest larval concentrations (Fig. 2). May was an exception to the general pattern, in that the distribution pattern was the converse, with the highest values for both number of species and number of individuals recorded near the coast, except in the southern portion of the study area (Fig. 2).

The overall PCA highlighted the importance of seasonality in the community structure, as shown by plot- 

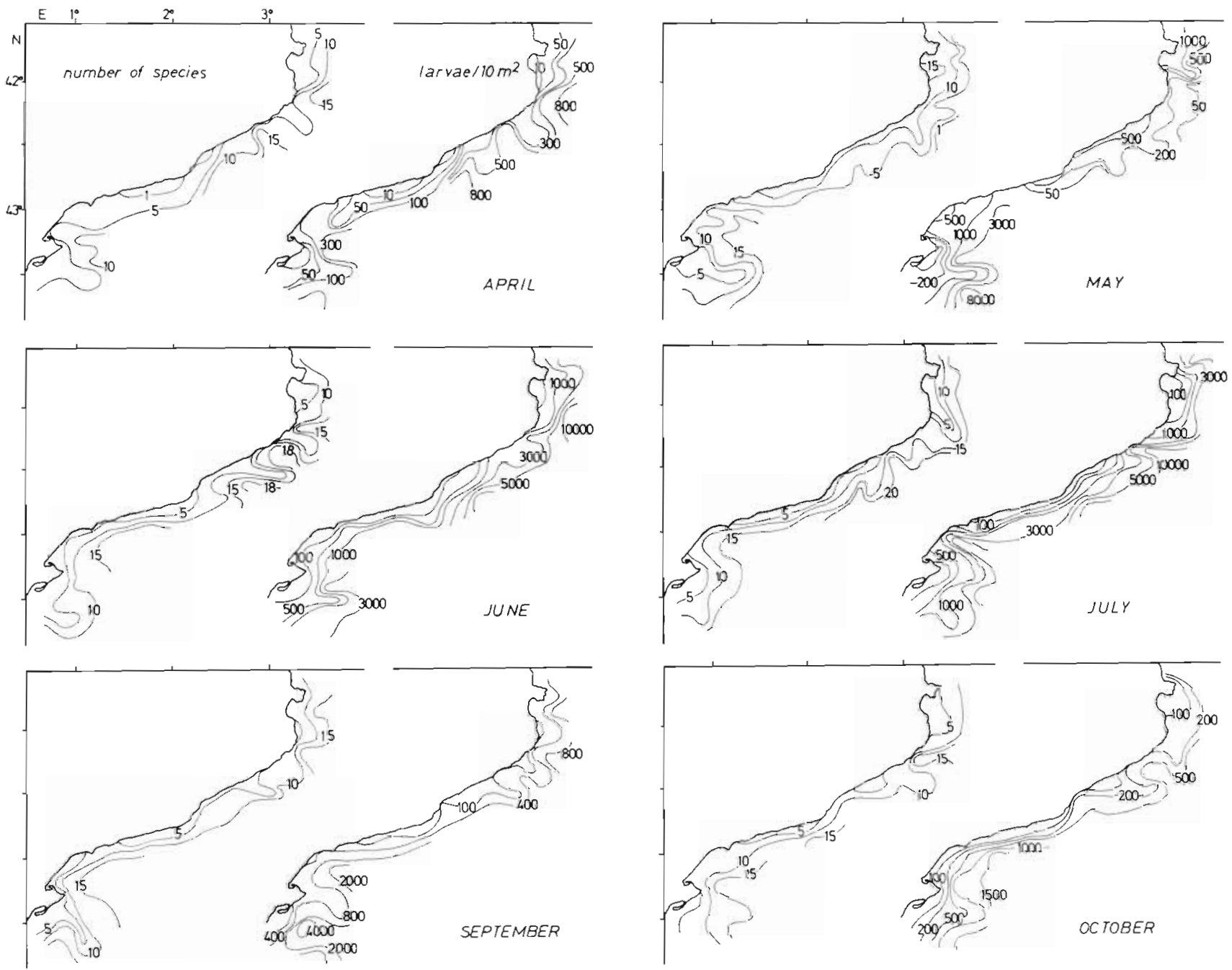

Fig. 2. Total number of species and number of individuals per $10 \mathrm{~m}^{2}$ during the 6 mo study period

ting the stations on the space defined by the first 2 axes. The April stations were located in the negative values on both axes, with the remaining months following in a clockwise direction (Fig. 3). The inshore stations located in the southern half of the area (the same ones each month), where the number of species present was nil or extremely low, were clustered with the slightly negative values on both axes. Certain stations in June and July were separated from the central cluster: these stations were situated over the Blanes and Palamós canyons, where large numbers of both species and individuals were collected in those months

Plotting the species in the space of the first 2 axes in the second PCA showed those species predominating at the shallowest stations to be concentrated in the negative values on the first axis (Fig. 4). Some species were localized in the Ebro River delta region (Sardinella aurita and Pomatomus saltator), while others exhibited a broader distribution pattern extending all along the coast (e.g. Buglossidium luteum, Diplodus sargus). The species with maximum abundance at the deepest stations had positive loadings on the first axis, with the most abundant myctophids, like Benthosema glaciale, Myctophum punctatum, and Lampanyctus crocodilus, located in this region. Although Engraulis encrasicholus larvae were found all over the area, the highest concentrations were recorded at the stations furthest offshore, mainly in the northern half of the area (Palomera 1989). The species occurring mainly in those regions where the continental shelf was broadest e.g. Cepola macrophtalma, Ophidion barbatum, and Symphurus nigrescens, were clustered with positive values on the second axis, while the mesopelagic species located over the $200 \mathrm{~m}$ isobath were grouped at the other end of the axis. Between these 2 most highly differentiated groups of species there were other 


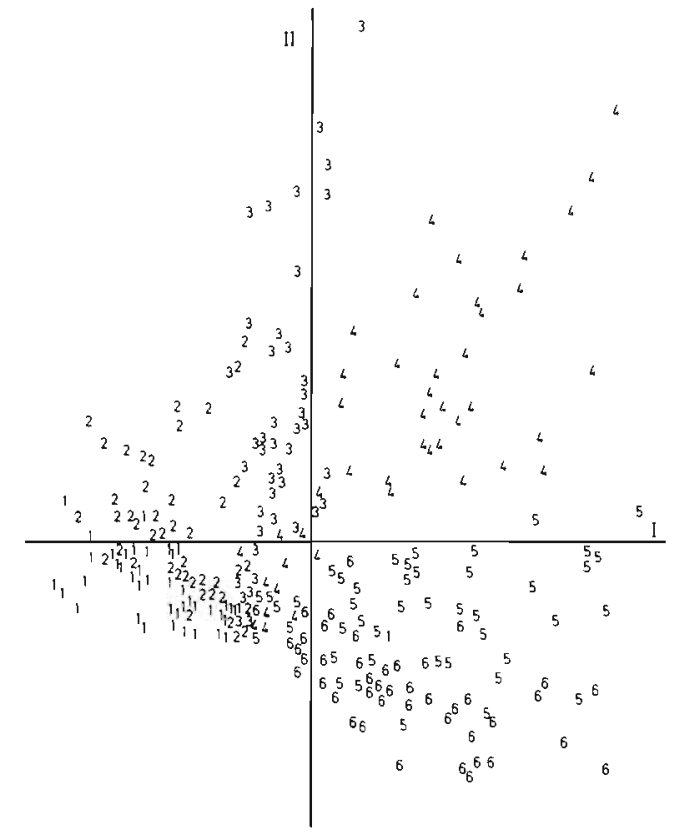

Fig. 3. Plot of stations in the space of the first 2 axes in the overall PCA (1: April, 2: May, 3: June, 4: July, 5: September, 6: October)

species widely distributed between the coast and the slope, like Sardina pilchardus, Scomber japonicus, and Auxis rochei.

Plotting the sample scores for the first factor on the station map showed that the most inshore samples yielded negative values, while those from furthest offshore or inshore over submarine canyons gave positive values. In fact, the positive values clearly followed the

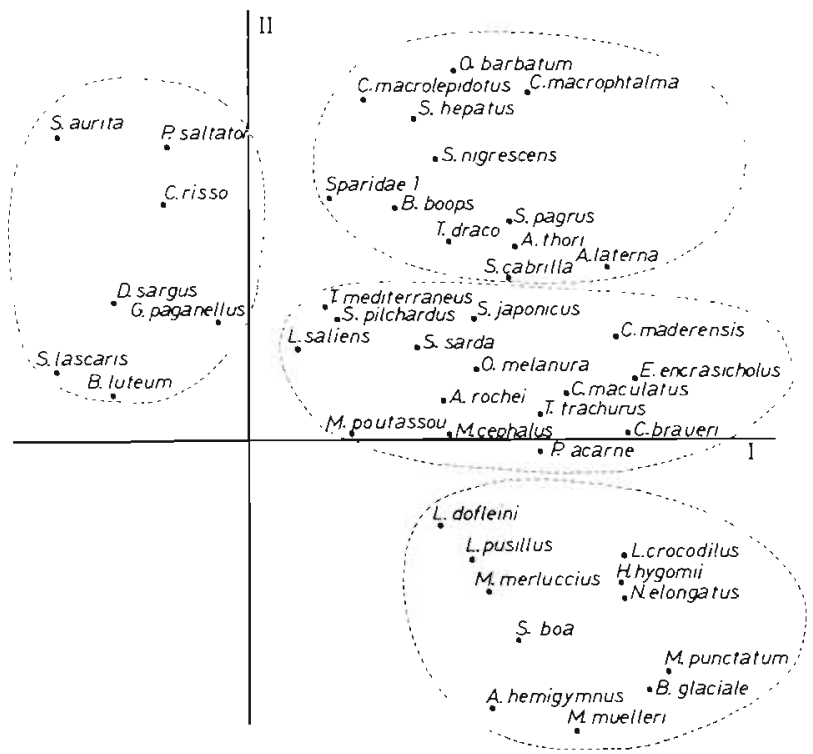

Fig. 4. Plot of species in the space of the first 2 axes in the PCA performed using the matrix of mean values (variance explained by the first factor: $22.65 \%$; by the second factor $12.61 \%$
$200 \mathrm{~m}$ isobath (Fig. 5). This factor is, therefore, clearly depth-related. The plots for the second factor showed that samples or stations yielding positive values came from the regions where the continental shelf was broadest, opposite the Ebro River delta in the south and between submarine canyons in the north. The stations located furthest offshore, and some from close inshore in the central part of the area, gave negative values (Fig. 5). The second axis thus appears to be related to bottom structure and type by differentiating the shelf regions from the rest of the coast.

The distribution of samples (stations) in the space defined by the first 2 axes yielded 4 well-defined groups of stations (Fig. 6). These 4 groups are clearly depicted in Fig. 7. Table 2 reflects species frequency in each of the 4 groups considered thereby defining the most characteristic species in each cluster. The 4 aggregations thus defined were:

(1) Inshore/coastal: there were practically no characteristic species in this zone, except for some specimens of Solea lascaris south of Barcelona and Pomatomus saltator opposite the Ebro River mouth. Larval abundance was generally low in this group.

(2) Coastal-shelf: the adults of the coastal and shelf species characteristic of this aggregation, e.g. Cepola macrophtalma, Symphurus nigrescens and Serranus hepatus were mainly benthic, dwelling over sea-grass and rocky bottoms.

(3) Shelf: the species making up this group had a broader distribution than the species in the previous 2 groups and were located both over the shelf and the most offshore stations in the deepest waters. The adults of most of these species, e.g. Scomber japonicus, Liza saliens and Trachurus trachurus, were pelagic and less dependent upon the substrate than the adults of the species in the preceding groups, hence having a much wider distribution.

(4) Shelf-slope: the representative species in this group, e.g. Maurolicus muelleri, Myctophum punctatum, and Lampanyctus crocodilus, were located over the edge of the continental shelf. The adults were mesopelagic inhabiting the oceanic region at considerable depth.

\section{DISCUSSION}

Distribution patterns in larval fish communities, as in other zooplankton groups, result from a combination of factors that usually gives rise to spatiotemporal heterogeneity. A distribution pattern like that described above is the immediate consequence of species variation, with seasonal heterogeneity as the main characteristic reflected in the overall PCA. Such temporal fluctuations are mainly due to seasonal spawning cycles. Specifically, in the study area, species with 


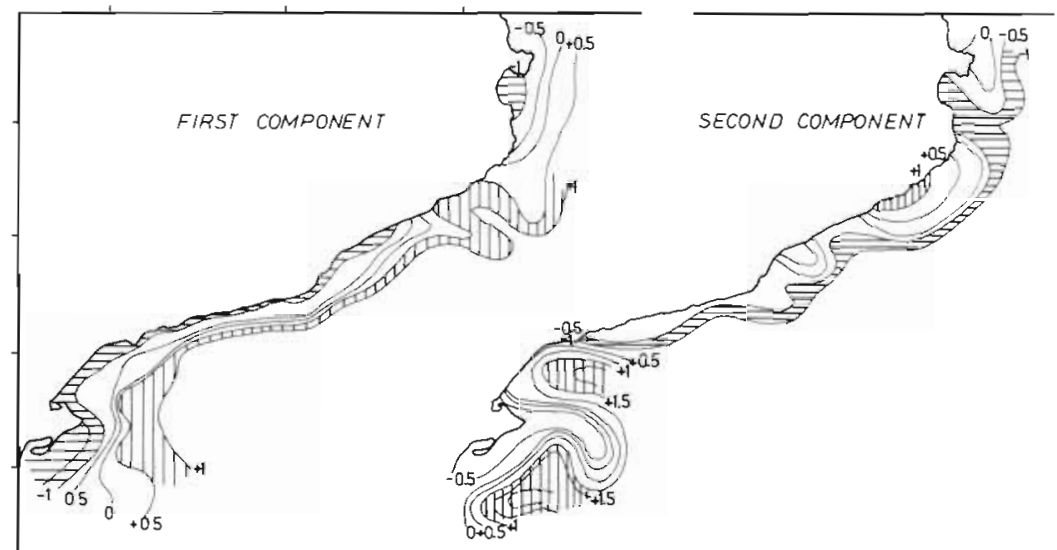

Fig. 5. Spatial plot of station scores of the first 2 factors obtained in the PCA performed using the matrix of mean values; refer to text and Fig. 7 for explanation of the 4 clusters

inshore-dwelling adults like sparids and labrids show marked seasonal variability (Harmelin 1987); their spawning periods may be very short (Sabatés 1988). Furthermore, compared to other regions, where mesopelagic fish spawning has been reported to occur through the year (Gjøsaeter \& Kawaguchi 1980), some of these species present well-defined spawning peaks in the Mediterranean (Goodyear et al. 1972, Sabatés \& Olivar 1989).

In other coastal areas, where environmental instability is higher than in the open ocean, seasonality has also been reported to be an important factor contributing to general distribution patterns of larval fish communities (Loeb 1979, Richardson et al. 1980). This contrast with the findings of Young et al. (1986) off Western Australia, where seasonality was not regarded a major factor affecting the larval distribution pattern. However, these authors used higher categories than species (families) as taxa to define different larval assemblages, and spawning period variability for the different species within a family may thus have been concealed within a general pattern.

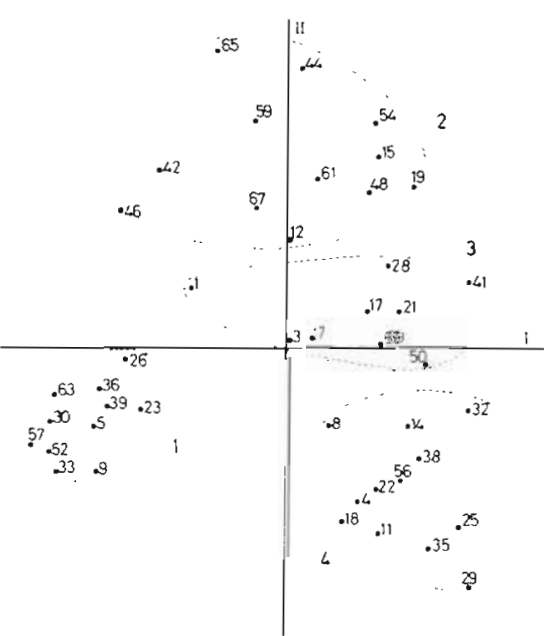

Fig. 6. Plot of stations in the space of the first 2 axes in the PCA performed using the matrix of mean values
When the seasonal component was removed, the second PCA showed a spatial distribution pattern that remained more or less constant over the 6 mo study period (Sabatés 1988), as a result of the persistence of phenomena regulating hydrodynamic variability off the Catalan coast (Font 1986). Plotting the 4 groups defined in the second PCA on the station map (Fig. 7) clearly shows the coincidence with depth and bottom type of the Catalan coast (Fig. 1). Moreover, assemblage definition is closely related to adult habitat and behaviour. However, because of the diversity of features in the Catalan coastal region, species do not belong exclusively to a single group, although distinct trends in relative species abundance are distinguishable in the assemblages considered (Table 2). Thus, on the broader shelf regions the coastal or coastal-shelf assemblages are more clearly separated from the shelf assemblage, which in turn is separated from the shelfslope assemblage. The nature of the substrate also

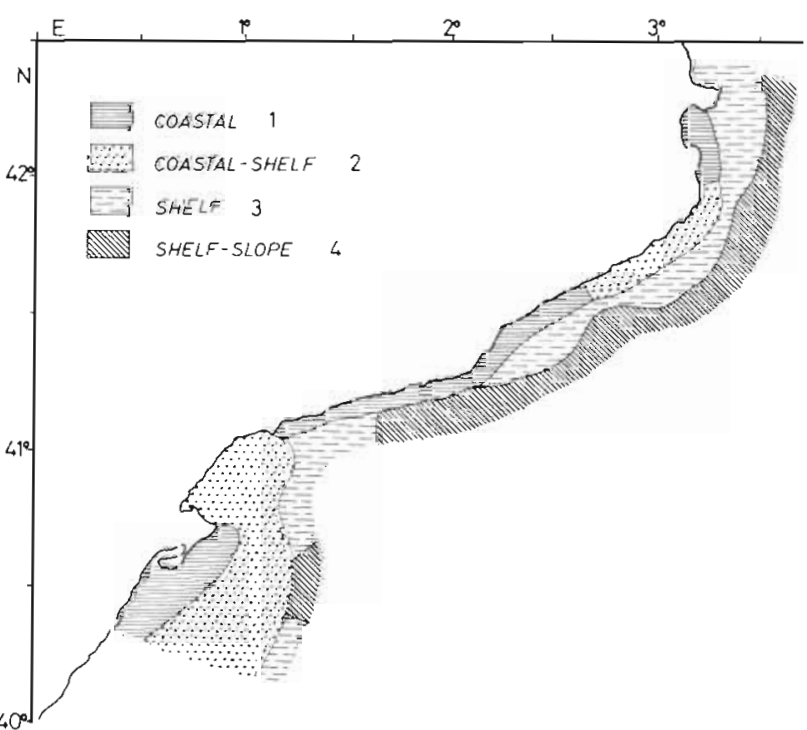

Fig. 7. Plot of the 4 zones differentiated by the PCA performed using the matrix of mean values, corresponding to the 4 species assemblages 
Table 2. Percentage of species occurrence in each of the 4 areas identified by the PCA (number of samples within a group in parentheses)

\begin{tabular}{|c|c|c|c|c|}
\hline Species & $\begin{array}{c}1 \\
\%(66)\end{array}$ & $\begin{array}{c}2 \\
\%(72)\end{array}$ & $\begin{array}{l}3 \\
\%(53)\end{array}$ & $\begin{array}{l}4 \\
\%(72)\end{array}$ \\
\hline Sardina pilchardus & 21 & 21 & 15 & 12 \\
\hline Sardinella aurita & 23 & 26 & 11 & 17 \\
\hline Engraulis encrasicholus & 59 & 73 & 70 & 57 \\
\hline Cyclothone braueri & 17 & 36 & 43 & 49 \\
\hline Maurolicus muelleri & - & 3 & 15 & 43 \\
\hline Argyropelecus hemigymnus & - & 1 & 8 & 29 \\
\hline Stomias b. boa & - & 1 & 13 & 15 \\
\hline Benthosema glaciale & - & 8 & 38 & 53 \\
\hline Hygophum hygomii & - & 7 & 25 & 22 \\
\hline Myctophum punctatum & - & 11 & 47 & 56 \\
\hline Lobianchia dofleini & 2 & 1 & 6 & 7 \\
\hline Lampanyctus crocodilus & 9 & 26 & 26 & 37 \\
\hline Lampanyctus pusillus & 2 & 4 & 4 & 11 \\
\hline Ceratoscopelus maderensis & 12 & 31 & 47 & 32 \\
\hline Notoscopelus elongatus & - & 7 & 15 & 17 \\
\hline Micromesistius poutassou & - & 6 & 2 & 10 \\
\hline Merluccius merluccius & - & 6 & 17 & 22 \\
\hline Ophidion barbatum & 11 & 24 & 27 & 15 \\
\hline Serranus cabrilla & - & 6 & 6 & 4 \\
\hline Serranus hepatus & 9 & 40 & 38 & 21 \\
\hline Pomatomus saltator & 9 & 21 & 6 & 3 \\
\hline Trachurus m, mediterraneus & - & 11 & 11 & 10 \\
\hline Trachurus trachurus & 12 & 29 & 45 & 25 \\
\hline Boops boops & 21 & 29 & 28 & 24 \\
\hline Diplodus s. sargus & 12 & 17 & 13 & 4 \\
\hline Oblada melanura & 9 & 12 & 13 & 11 \\
\hline Pagellus acarne & 15 & 20 & 22 & 18 \\
\hline Sparus pagrus & 6 & 24 & 27 & 17 \\
\hline Sparidae Type 1 & 8 & 24 & 19 & 4 \\
\hline Cepola macrophtalma & 21 & 69 & 62 & 37 \\
\hline Liza saliens & 9 & 12 & 15 & 10 \\
\hline Mugil c. cephalus & 6 & 11 & 15 & 12 \\
\hline Trachinus draco & 6 & 28 & 17 & 19 \\
\hline Callionymus maculatus & 8 & 28 & 30 & 31 \\
\hline Callionymus risso & 20 & 31 & 19 & 10 \\
\hline Gobius paganellus & 3 & 6 & 4 & 1 \\
\hline Auxis rochei & 3 & 11 & 8 & 11 \\
\hline Sarda sarda & - & 7 & 2 & 7 \\
\hline Scomber japonicus & 3 & 15 & 13 & 15 \\
\hline Citharus macrolepidotus & - & 21 & 8 & 7 \\
\hline Arnoglossus laterna & 6 & 39 & 38 & 15 \\
\hline Arnoglossus thori & 6 & 27 & 26 & 13 \\
\hline Symphurus nigrescens & - & 26 & 11 & 10 \\
\hline Buglossidium luteum & 18 & 14 & 19 & 6 \\
\hline Solea lascaris & 8 & - & - & 1 \\
\hline
\end{tabular}

contributes to the separation. Where the shelf is broader the different substrates cover larger areas, thereby more clearly delimiting the habitats of the adults, particularly in the case of demersal species. This distribution pattern does not seem to be affected by local advection processes like seaward surface transport, which contributes to the transport of inshore larvae to the open sea (Lobel \& Robinson 1986). On the Catalan coast, larvae were never detected far from the adult habitats, which suggests that while transport may occur locally, it is not overly important. The fact that larvae were found not far from the spawning area might imply an advantage for the recruitment of this species in the area.

The spatial heterogeneity observed of the Catalan coast was similar to that reported by Leis \& Miller (1976) off Hawaii, where the continental shelf is also relatively narrow, and these authors established associations based on adult habitat and spawning strategy. Like on the Catalan coast, shorefish larvae were sometimes present in the region further offshore; similarly, species from the oceanic group could be found in more inshore waters. In other regions where the continental shelf is broad, as the Northeastern Pacific off Oregon (Richardson \& Pearcy 1977, Richardson et al. 1980) and Northwest Australia (Young et al. 1986), shelf and oceanic associations have been detected, often separated by an intermediate zone containing a transitional association. Unlike the Catalan coast, the species in the coastal and oceanic associations were almost never found together. This suggests that in coastal areas in which shelf structure is highly variable, the spatial distribution of larvae is quite heterogeneous, which involves the coexistence of a great number of species in the same area.

The existence of the shelf slope-front, associated with the current flowing parallel to the coast, contributes to larval concentrations of both mesopelagic and shelf species over the shelf break. This is most evident from the maximum concentration values for the number of species and individuals recorded over the edge of the shelf. Frontal structures of this kind also generate larval concentrations in other regions, such as over the Grand Bank off Newfoundland (Anderson \& Gardner 1986) or the North Sea (Kiørboe et al. 1988). This agrees with the findings for most of the zooplankton groups in the area (Sabatés et al. 1989), and may be due to enhanced mixing in this region giving rise to high productivity (Le Fèvre 1986). In addition, this front could act as a barrier preventing the offshore dispersion of coastal and shelf species. As Iles \& Sinclair (1982) argued, the existence of geographically larval retention areas is an important mechanism in the maintenance of discrete stocks of larval populations.

It can therefore be concluded that the main factors affecting the spatiotemporal distribution pattern of fish larvae in the Catalan coast include shelf topography and bottom type, adult habitat and behaviour, spawning locality, and spawning period. Mesoscale hydrodynamic factors also play an important role in the observed spatiotemporal heterogeneity, particularly the existence of the shelf-slope front, which contributes to largest larval concentrations and highest specific richness offshore. 
Acknowledgements. This study was carried out with partial financial support of the Fundación Ramon Areces. I thank all the members of the Areces program for their collaboration during the sampling. I thank to my colleagues Dr M. P. Olivar for making useful suggestions and Dr J.M. Gili for their comments and critical reading of the original manuscript. Also thanks to Dr E. Macpherson for his valuable help and Mr J. Murillo for his advice in the statistical analyses.

\section{LITERATURE CITED}

Aboussouan, A. (1964). Contribution à l'étude des oeufs et larves pélagiques des poissons téléostéens dans le golfe de Marseille. Recl Trav. Stn mar. Endoume 32 (48): 87-171

Anderson, J. T., Gardner, G. A. (1986). Plankton communities and physical oceanography observed on the Southeast Shoal region, Grand Bank of Newfoundland. J. Plankton Res. 8 (6): 1111-1135

Colebrook, J. M. (1964). Continuous plankton recorded: a principal component analysis of the geographical distribution of zooplankton. Bull. mar. Ecol. 6: 78-100

Denman, K. L., Powell, T. M. \{1984\}. Effects of physical processes on planktonic ecosystems in the coastal ocean. Oceanogr, mar. Biol. A. Rev. 22: 125-168

Font, J. (1986). La circulació general a la Mar Catalana. Ph.D. thesis, University of Barcelona

Font, J., Salat, J., Tintoré, J. (1988). Permanent features in the circulation of the Catalan Sea. In: Minas, H. J., Nival, P (eds.) Oceanologica Acta, Special issue 'Océanographie pelagique méditerranéenne' 9: 51-57

Gili, J. M., Ros, J. D., Pagés, F. (1987). Types of bottoms and benthic cnidaria from the trawling grounds (littoral and bathyal) off Catalonia (NE Spain). Vie Milieu 37 (2): 85-98

Gjosaeter, J., Kawaguchi, K. (1980). A review of the world resources of mesopelagic fish. FAO Fish. tech. Pap. 193: 1-151

Goodyear, R. H., Zahuranec, B. J., Pugh, W L., Gibbs, R. H. (1972). Ecology and vertical distribution of Mediterranean midwater fishes. Mediterr. biol. Stud. final Rep. 1: 91-229

Harmelin, J.-G. (1987). Structure et variabilité del'ichthyofaune d'une zone rocheuse protegée en Méditerranée (Parc national de Port-Cros, France). P.S.Z.N.I. Mar. Ecol. 8 (3): 263-284

Haury, L. R., Pieper, R. E. (1988). Zooplankton: scales of biological and physical events. In: Soule, D. F. Kleppel, G. $\mathrm{S}$. (eds.) Marine organisms as indicators. Springer-Verlag. Berlin, p. 35-72

Ibanez, F. (1976). Contribution à l'analyse mathématique des événements en écologie planctonique. Bull. Inst. océanogr Monaco 72: 1-96

Ibanez, F., Seguin, G. (1972). Etude du cycle annuel du zooplancton d'Abidjan. Comparaison de plusieurs méthodes d'analyse multivariable: composants principales, correspondances, coordonnées principales. Investigación pesq. 36 (1): $81-108$

lles, T D., Sinclair, M. (1982). Atlantic herring: stock discreteness and abundance. Science 215: 627-633

Kiørboe, T., Munk, P., Richardson, K., Christensen, V.,

This article was submitted to the editor
Paulsen, H. (1988). Plankton dynamics and larval herring growth, drift and survival in a frontal area. Mar. Ecol. Prog. Ser. 44: 205-219

Le Fèvre, J. (1986). Aspects of the biology of frontal systems. Adv. mar. Biol. 23: 163-299

Legendre, L., Demers, S. (1984). Towards dynamic biological oceanography and limnology. Can. J. Fish. Aquat. Sci. 41: 2-19

Leis, J M., Miller, J. M. (1976). Offshore distributional patterns of hawaiian fish larvae. Mar. Biol. 36: 359-367

Lobel, P. S., Robinson, A. R. (1986). Transport and entrapment of fish larvae by ocean mesoscale eddies and currents in Hawaiian waters. Deep Sea Res. 33 (4): 483-500

Loeb. V. J. (1979). Larval fishes in the zooplankton community of the North Pacific central gyre. Mar. Biol. 53: 173-191

Mackas, D. L., Denman, K. L., Abbot, M. R. (1985). Plankton patchiness: Biology in the physical vernacular. Bull. mar. Sci. 37 (2): 652-674

Marinaro, J.-Y (1971). Contribution à l'étude des oeufs et larves pélagiques de poissons méditérranéens. V Oeufs pélagiques de la baie d'Alger. Pelagos 3 (1): 1-115

Palomera, I. (1989). Primeras fases del desarrollo de la anchoa en la costa catalana. Ph.D. thesis, University of Barcelona

Richardson, S. L., Laroche, J. L., Richardson, M. D. (1980), Larval fish assemblages and associations in the north-east Pacific coast along the Oregon coast, winter-spring 1972-1975. Estuar. cstl mar. Sci. 11: 671-699

Richardson, S. L., Pearcy, W. G. (1977). Coastal and oceanic larvae in an area of upwelling off Yaquima Bay, Oregon. Fish. Bull. U.S. 75 (1): 125-145

Sabatés, A (1988). Sistemática y distribución espacio-temporal del ictioplancton en la costa Catalana. Ph.D thesis, University of Barcelona

Sabatés, A., Olivar, M. P. (1989). Comparative spawning strategies of mesopelagic fishes in two marine systems with different productivity. Rapp. P.-v. Réun. Cons. int. Explor. Mer 191. (in press)

Sabatés, A., Gili, J. M., Pagés, F. (1989). Relationship between zooplankton distribution, geographic characteristics and hydrographic patterns off the Catalan coast (Western Mediterranean). Mar. Biol. 103: 153-159

Salat, J., Font, J. (1987). Water mass structure near and offshore the Catalan coast during the winter of 1982 and 1983. Annls Géophys. 5: 49-54

Shapiro, D. Y., Hensley, D. A., Appeldoorn, R. S. (1988). Pelagic spawning and egg transport in coral reef fishes: a skeptical overview. Environ. Biol. Fish. 22 (1): 3-14

Young, P. C., Leis, J. M., Hausfeld, H. F. (1986). Seasonal and spatial distribution of fish larvae in waters over the North West Continental Shelf of Western Australia. Mar Ecol. Prog. Ser 31: 209-222

Walker, H. J. Jr, Watson W., Barnett, A. M. (1987). Seasonal occurrence of larval fishes in the nearshore southern California Bight off San Onofre, California. Estuar. cstl Shelf Sci. 25: 91-109

Wang, D. P., Vieira, M. E. C., Salat, J., Tuntoré, J. (1988). A shelf slope filament off Northeast spanish coast. J. mar. Res. 46: 321-332

Manuscript first received: April 13, 1989

Revised version accepted: September 15, 1989 